Pawet Gata

\title{
Odstępstwo rolne na tle innych licencji ustawowych
}

\section{Zagadnienia wprowadzające}

Korzystanie z dóbr niematerialnych stanowi w rozwiniętych systemach gospodarki rynkowej istotny czynnik rozwojowy. Służy przede wszystkim osiąganiu przychodów, ale również zaspokajaniu zarówno podstawowych, jak i wyższych potrzeb społecznych. Istnieje kilka możliwości zgodnego z prawem posługiwania się dobrami niematerialnymi:

- można takie dobro wytworzyć, czyli korzystać z niego jako jego twórca;

- można dobro niematerialne nabyć od podmiotu, któremu przysługują prawa do takiego dobra;

- można wreszcie korzystać z cudzego dobra niematerialnego w zakresie wynikającym $z$ upoważnienia udzielonego przez podmiot uprawniony lub przepis prawa.

Koncentrując się nad trzecią z przedstawionych możliwości, podkreślić należy, że upoważnienie do korzystania $\mathrm{z}$ dobra o charakterze niematerialnym nosi powszechnie miano licencji. W systemie ochrony dóbr niematerialnych wyróżnić można dwa zasadnicze typy licencji:

- licencje umowne,

- licencje ustawowe.

Jednocześnie wskazać można na dwa podstawowe kryteria takiego rozróżnienia.

Pierwsze z nich polega na wyróżnieniu wspomnianych wyżej kategorii w kontekście konieczności uzyskiwania zgody podmiotu uprawnionego na korzystanie $\mathrm{z}$ dobra niematerialnego. W przypadku licencji umownych zgoda podmiotu uprawnionego jest koniecznym elementem składowym konsensusu, który składa się na treść zawieranej przez strony umowy. W przypadku licencji ustawowych zgoda taka nie jest konieczna, a podstawą zawiązania węzła obligacyjnego pomiędzy podmio- 
tem korzystającym z prawa niematerialnego a podmiotem uprawnionym jest przepis prawa.

Drugim kryterium rozróżnienia jest cel funkcjonowania każdego z wymienionych typów licencji w obrocie prawnym. Licencje umowne są podstawowym źródłem czerpania przez podmioty uprawnione korzyści z owoców swojej pracy intelektualnej. Ustalone w takich umowach opłaty licencyjne stanowią przychód uprawnionego, a często również zapewniają ekonomiczną bazę dla dalszej pracy twórczej. Licencje ustawowe są natomiast wyrazem ochrony interesów publicznych przed ograniczaniem dostępu do dóbr o charakterze intelektualnym. Kształtując licencje ustawowe, prawodawca przyjmuje założenie, że w niektórych przypadkach uzależnienie skorzystania $\mathrm{z}$ dobra niematerialnego od zgody jego wyłącznego dysponenta byłoby niecelowe, podobnie jak niecelowa byłaby nieograniczona możliwość żądania przez uprawnionego wynagrodzenia za każde bez wyjątku wykorzystanie dobra intelektualnego.

W ramach funkcjonującego w Polsce systemu ochrony dób niematerialnych można również dokonać klasyfikacji samych tylko licencji ustawowych, wyróżniając:

- licencje przymusowe,

- dozwolony użytek prywatny,

- dozwolony użytek publiczny,

- odstępstwo rolne.

Wskazane wyżej licencje ustawowe unormowane zostały w trzech podstawowych grupach uregulowań składających się na polski system ochrony dóbr niematerialnych:

- przepisach dotyczących prawa autorskiego i praw pokrewnych - statuujących ochronę wyłącznego prawa do utworów głównie o charakterze artystycznym,

- przepisach dotyczących własności przemysłowej - statuujących ochronę dóbr niematerialnych o charakterze technicznym oraz czysto komercyjnym,

- przepisach ze sfery prawa rolnego - statuujących ochronę wyłącznego prawa do odmian roślin.

Przedmiotem niniejszego opracowania jest próba wskazania miejsca odstępstwa rolnego - licencji ustawowej prawa rolnego w polskim systemie ochrony dóbr niematerialnych w kontekście innych licencji ustawowych. 


\section{Odstępstwo rolne}

Sui generis model ochrony wyłącznego prawa do odmian roślin uprawnych oparty jest trzech typach unormowań:

- przepisach międzynarodowych;

- przepisach wspólnotowych;

- uregulowaniach krajowych.

Podkreślić należy, że unormowania krajowe oraz wspólnotowe funkcjonują w polskim porządku prawnym równolegle i bezkolizyjnie. Na gruncie każdego z tych uregulowań prawodawca przewidział funkcjonowanie licencji ustawowej, której celem jest ochrona podstawowego interesu społecznego, jakim jest zapewnienie ciągłości roślinnej produkcji rolniczej. Pojęciem odstępstwa rolnego, dla oznaczenia tej właśnie licencji ustawowej, po raz pierwszy posłużył się prawodawca wspólnotowy w tytule Rozporządzenia Komisji (WE) nr 1768/95 ustanawiającego przepisy wykonawcze w zakresie odstępstwa rolnego przewidzianego w art. 14 ust. 3 rozporządzenia Rady (WE) nr 2100/94 w sprawie wspólnotowego systemu ochrony odmian roślin oraz w jego preambule.

Kompleksowa analiza zarówno krajowych, jak i wspólnotowych przepisów prawa regulujących problematykę ochrony wyłącznego prawa do odmian roślin pozwala przyjąć, iż przez pojęcie odstępstwa rolnego należy rozumieć odstępstwo od przyjętego systemu ochrony odmian roślin w celu zabezpieczenia interesów rolników. Przy czym realizacja interesów rolników polega na możliwości wykorzystywania przez nich we własnym gospodarstwie materiału ze zbioru odmiany chronionej jako materiału siewnego bez zgody hodowcy za stosowną opłatą lub bez obowiązku jej uiszczania.

Rozumiane w ten sposób odstępstwo rolne stanowi wyjątek od generalnej reguły, iż podejmowanie działań składających się na wyłączne prawo do odmiany w stosunku do materiału siewnego tej odmiany wymaga zgody uprawnionego hodowcy. Instytucja odstępstwa rolnego czyni wyłom w tej zasadzie.

Immanentnym aspektem instytucji odstępstwa rolnego jest jej „wewnętrzne” ograniczenie. Przejawia się ono w możliwości stosowania odstępstwa rolnego jedynie w odniesieniu do wskazanych przez prawodawcę gatunków roślin uprawnych istotnych ze społeczno-gospodarczego punktu widzenia.

\section{Odstępstwo rolne na tle licencji przymusowych}

Licencja przymusowa jest specyficznym typem licencji ustawowej, a nie brak również w literaturze koncepcji przemawiających za uznaniem jej jako odrębnego typu licencji funkcjonującego obok licencji umownych oraz ustawowych. Licen- 
cja przymusowa spełnia jednak kryteria licencji ustawowych, o których była wyżej mowa, tzn. jej przyznanie jest niezależne od woli podmiotu uprawnionego z tytułu prawa wyłącznego oraz służy realizacji istotnego interesu społecznego.

Specyficzną cechą wyróżniającą licencje przymusowe na tle innych licencji ustawowych jest sposób zawiązywania węzła obligacyjnego licencji przymusowej pomiędzy podmiotem uprawnionym a licencjobiorcą korzystającym z dobra niematerialnego w oparciu o taką licencję. Do udzielenia licencji przymusowej nie jest bowiem wystarczający sam przepis prawa, ale konieczne jest dodatkowo działanie podmiotu trzeciego, zewnętrznego z punktu widzenia stosunku obligacyjnego. Podmiotem takim jest organ publiczny, którego zadaniem jest badanie faktu zaistnienia przesłanek dla udzielenia licencji przymusowej oraz określenie zakresu takiej licencji.

Licencja przymusowa jest charakterystycznym instrumentem polskiego prawa własności przemysłowej. Uregulowana została przepisami art. 82-88 ustawy z dnia 30 czerwca 2000 r. Prawo własności przemysłowej ${ }^{1}$. Zgodnie z tą regulacją, podmiotem decydującym o udzieleniu licencji przymusowej jest Urząd Patentowy Rzeczypospolitej Polskiej - centralny organ administracji rządowej podlegający Radzie Ministrów. Udziela on licencji przymusowej na korzystanie z opatentowanego wynalazku w przypadku, gdy:

- jest to konieczne do zapobieżenia lub usunięcia stanu zagrożenia bezpieczeństwa Państwa, w szczególności w dziedzinie obronności, porządku publicznego, ochrony życia i zdrowia ludzkiego oraz ochrony środowiska naturalnego;

- zostanie stwierdzone, że patent jest nadużywany, lub

- zostanie stwierdzone, że licencja przymusowa jest konieczna dla korzystania z patentu zależnego, który ma szczególne znaczenie dla postępu technicznego.

Licencja przymusowa nie jest natomiast znana polskiemu prawu autorskiemu oraz prawom pokrewnym. Przyczyna takiego stanu rzeczy jest oczywista. Cechą charakterystyczną licencji przymusowej, o czym już wcześniej była mowa, jest to, iż jest ona udzielana przez podmiot zewnętrzny, który posiada nie tylko ustawową legitymację do takiego działania, ale i możliwości udzielenia takiego upoważnienia. $\mathrm{W}$ istocie zatem, podmiot taki musi dysponować dobrem niematerialnym w zakresie koniecznym do udzielenia licencji przymusowej. W ramach prawa własności przedmiotowej Urząd Patentowy dysponuje szczegółowym opisem opatentowanego wynalazku, co pozwala na precyzyjne uregulowanie zakresu funkcjonowania licencji przymusowej. Utwory chronione w oparciu o regulacje prawa autorskiego uzyskują 
ochronę $\mathrm{w}$ chwili ich ustalenia $\mathrm{w}$ jakiejkolwiek formie bez potrzeby podejmowania zabiegów formalnych, w tym rejestracji. Dlatego też brak jest jakiegokolwiek podmiotu, za wyjątkiem uprawnionego do utworu, który dysponowałby utworem w zakresie wystarczającym do udzielenia licencji przymusowej. Nie bez znaczenia pozostaje również fakt, że licencja przymusowa jest instrumentem prawa chroniącym szczególnie ważne, podstawowe interesy społeczne, takie jak: zagwarantowanie bezpieczeństwa obywateli, ochrony życia lub zdrowia itp. Wynalazki mogą przyczyniać się do realizacji takich podstawowych interesów społecznych, zwłaszcza jeżeli funkcjonują w sferze np. przemysłu zbrojeniowego czy farmaceutycznego. Utwory podlegające ochronie w oparciu o przepisy prawa autorskiego służą w znakomitej większości zaspokajaniu potrzeb społecznych o innym charakterze. Zazwyczaj będą to potrzeby wyższego rzędu związane z oświatą, kulturą, informacją, nie zaś bieżące potrzeby związane z egzystencją człowieka.

Należy zatem rozważyć, czy odstępstwo rolne w postaci wcześniej zdefiniowanej mieści się w kategorii licencji przymusowych oraz czy w swojej konstrukcji posiada elementy zbliżające tę instytucję do licencji przymusowej. Na obydwa tak postawione pytania należy odpowiedzieć negatywnie.

Przede wszystkim, źródłem stosunków zobowiązaniowych odstępstwa rolnego jest przepis prawa, który wiąże określoną aktywność rolnika - wykorzystanie materiału ze zbioru odmiany chronionej wyłącznym prawem jako materiału siewnego z powstaniem węzła obligacyjnego. Brak jest zatem podmiotu trzeciego, który decydowałby o udzieleniu upoważnienia. Dodatkowo, przepisy regulujące problematykę ochrony wyłącznego prawa do odmian zarówno na szczeblu krajowym, jak i wspólnotowym, przewidują odrębną od odstępstwa rolnego licencję przymusową. $\mathrm{Na}$ szczeblu wspólnotowym licencja przymusowa została uregulowana przepisem art. 29 Rozporządzenia Rady (WE) nr 2100/94 z dnia 27 lipca 1994 r. w sprawie wspólnotowego systemu ochrony odmian roślin. Na mocy tego unormowania Wspólnotowy Urząd Ochrony Odmian Roślin udziela licencji przymusowej, gdy przemawia za tym interes publiczny. Zgodnie zaś z przepisami art. 31-35 ustawy z dnia 26 czerwca 2003 r. o ochronie prawnej odmian roślin, w przypadku odmian roślin chronionych na szczeblu krajowym, licencji przymusowej udziela minister właściwy dla spraw rolnictwa. Licencja taka udzielana jest, jeżeli hodowca posiadający wyłączne prawo do danej odmiany nie wprowadza jej materiału siewnego lub materiału ze zbioru do obrotu, a wymaga tego ważny interes gospodarczy.

Możliwość udzielenia licencji przymusowej wynika z faktu, że uzyskanie wyłącznego prawa do odmiany wymaga zachowania procedury rejestracyjnej, która wiąże się z możliwością dysponowania odmianą w zakresie umożliwiającym udzielenia takiej licencji. W omawianym zakresie regulacja wyłącznego prawa do odmian bliższa jest zatem regulacji prawa przemysłowego niż regulacji autorskoprawnej. 
Odstępstwo rolne jest zatem instytucją wyraźnie odrębną od licencji przymusowej, a jej cechy charakterystyczne ujawnią się dopiero w sytuacji porównania tej licencji ustawowej z dozwolonym użytkiem prywatnym oraz publicznym.

\section{Odstępstwo rolne a dozwolony użytek prywatny}

Pojęcia dozwolonego użytku prywatnego oraz dozwolonego użytku publicznego pozostają w ścisłym związku z regulacją polskiego prawa autorskiego, nie mieszczą się natomiast w konstrukcji praw na dobrach przemysłowych. Obejmują one swoim zakresem sytuacje, w których wskazane jest ograniczenie monopolu autorskiego, mimo że podmiotowi praw autorskich nadal przysługują prawa majątkowe do konkretnego dzieła. W zależności od społecznego kontekstu takich sytuacji, tzn. od tego, czy o zastosowaniu ograniczenia decyduje wzgląd na prywatny interes poszczególnych osób, czy też względy publiczne, dozwolony użytek przybiera postać prywatną lub publiczną.

Ustawa z dnia 4 lutego 1994 r. o prawie autorskim i prawach pokrewnych ${ }^{2}$ poświęca dozwolonemu użytkowi prywatnemu w zasadzie tylko jeden przepis art. 23. Przepis ten określa przypadki korzystania z danego dzieła do własnych prywatnych potrzeb, przy czym warunkiem legalności korzystania z tej licencji ustawowej jest to, aby wykorzystywany utwór był już rozpowszechniony, czyli został uprzednio publicznie udostępniony. Instytucja dozwolonego użytku prywatnego stanowi wyraz ograniczenia wyłącznego prawa do utworów ze względu na prowadzoną przez państwo politykę oświatową i kulturalną. Zagwarantowanie szerokiego i szybkiego dostępu ogółu do dóbr kultury nie może jednak odbywać się kosztem twórców, stąd też w ramach regulacji odnoszących się do tej licencji ustawowej konieczne było zrównoważenie interesów stron. Zapewnieniu tej równowagi posłużyły dwa rozwiązania prawne:

- ustanowienie wynagrodzenia z tytułu masowego zwielokrotniania na użytek prywatny (art. 20 i $20^{1}$ ustawy autorskiej),

- ustawowe sprecyzowanie kręgu osób objętych użytkiem osobistym (art. 23 ust. 2 ustawy).

Zakres przedmiotowy dozwolonego użytku prywatnego jest niezwykle szeroki. Obejmuje on większość utworów autorskoprawnych $\mathrm{z}$ wyłączeniem jedynie utworów architektonicznych, architektoniczno-urbanistycznych oraz elektronicznych baz danych. W tej sferze dozwolony użytek prywatny w sposób znaczący odróżnia się od funkcjonującej w prawie rolnym licencji ustawowej odstępstwa rolnego. Odstępstwo rolne obejmuje zakresem przedmiotowym jedynie enumeratywnie wskazane gatunki roślin. Prawodawca zarówno krajowy, jak i wspólnotowy, kształ- 
tując katalog gatunków roślin podlegających odstępstwu rolnemu, kierował się innymi względami, niż czynił to w przypadku autorskoprawnej instytucji dozwolonego użytku prywatnego. Dla potrzeb odstępstwa rolnego wytypowano najistotniejsze i najbardziej podstawowe gatunki roślin, dla osiągnięcia celu, jakim było zagwarantowanie ciągłości produkcji rolnej, a pośrednio bezpieczeństwa żywnościowego. Prawodawca nie brał natomiast pod uwagę wartości komercyjnej odmian należących do poszczególnych gatunków. Dla potrzeb dozwolonego użytku prywatnego zastosowano szeroką możliwość korzystania z dóbr intelektualnych, celem możliwie szybkiego i szerokiego dostępu do dóbr kultury. Z zakresu tej instytucji wyłączono natomiast dobra o szczególnej wartości komercyjnej oraz użytkowej, w przypadku których wartości artystyczne mogą odgrywać rolę drugoplanową.

Jeżeli natomiast idzie o zakres podmiotowy dozwolonego użytku prywatnego, to podkreślić należy, że w zasadzie nie ma żadnych ograniczeń podmiotowych co do możliwości skorzystania z tej instytucji prawa, z zastrzeżeniem, że korzystającym jest zawsze osoba fizyczna. Ograniczenie możliwości stosowania tej licencji ustawowej wyłącznie dla osób fizycznych wynika pośrednio z dwóch przyczyn. Po pierwsze, dozwolony użytek prywatny służyć ma celowi dostępu do dóbr kultury, zaś potrzeba taka realizowana jest przez osoby fizyczne indywidualnie, nie zaś przez podmioty funkcjonujące na zasadach swoistej fikcji prawnej, tj. osoby prawne, czy też jednostki organizacyjne nieposiadające osobowości prawnej. Po drugie, za możliwością stosowania dozwolonego użytku prywatnego wyłącznie przez osoby fizyczne przemawia unormowanie art. 23 ust. 2 ustawy, zgodnie z którym dobrodziejstwem tej instytucji, obok samego użytkownika, objęte są osoby pozostające $\mathrm{z}$ nim w stosunku osobistym, a więc osoby pokrewne, powinowate, a także pozostające w stosunku towarzystwa. Więzi takie wyraźnie zastrzeżone, z racji swojego charakteru, dla osób fizycznych.

Również w tym przypadku regulacja licencji ustawowej odstępstwa rolnego znacznie różni się od zasad, na jakich opiera się dozwolony użytek prywatny. Krąg podmiotów uprawnionych do korzystania z odstępstwa rolnego jest bowiem określony w odmienny sposób. Przede wszystkim obejmuje on ograniczony krąg podmiotów, tj. posiadaczy gruntów rolnych. Dodatkowo nie funkcjonuje tu ograniczenie wyłącznie do osób fizycznych. Z odstępstwa rolnego może korzystać każdy posiadacz gruntu rolnego (rolnik) bez względu na formę organizacyjno-prawną, w jakiej funkcjonuje. Jeżeli jednak rolnik taki decyduje się na wykorzystanie materiału ze zbioru odmiany chronionej wyłącznym prawem jako materiału siewnego, może tego dokonać wyłącznie we własnym gospodarstwie.

W odmienny sposób uregulowano również problematykę wynagrodzenia podmiotu uprawnionego z tytułu wyłącznego prawa w związku z korzystaniem z odstępstwa rolnego oraz dozwolonego użytku prywatnego. Osoby korzystające z dozwolo- 
nego użytku prywatnego koszty tego wynagrodzenia ponoszą w sposób pośredni, tj. poprzez konieczność nabywania urządzeń lub czystych nośników służących reprodukcji utworów. Opłata zaś uiszczana jest przez producentów oraz importerów takich urządzeń oraz nośników na rzecz organizacji zbiorowego zarządzania prawami autorskimi i pokrewnymi. Organizacje te zajmują się redystrybucją tego wynagrodzenia pomiędzy poszczególne podmioty uprawnione, posługując się przybliżonymi kalkulacjami opartymi na wynikach sprzedaży egzemplarzy utworów na rynku. W przypadku wyłącznego prawa do odmiany, podmioty korzystające $\mathrm{z}$ instytucji odstępstwa rolnego, poza kategorią drobnych rolników, zobowiązane są do wnoszenia opłat bezpośrednio na rzecz uprawnionych hodowców.

\section{Odstępstwo rolne a dozwolony użytek publiczny}

W odróżnieniu od dozwolonego użytku prywatnego, dozwolony użytek publiczny nie dotyczy utworów w ogólności, ale poszczególnych ich kategorii w zróżnicowanym zakresie. Dozwolonym użytkiem publicznym objęte są utwory, których użyteczność społeczna jest z różnych względów doniosła. Chodzi o możliwość realizowania dzięki nim m. in. celów edukacyjnych, informacyjnych, kulturotwórczych oraz naukowych. Biorąc pod uwagę przedmiotowe podobieństwa między poszczególnymi przypadkami dozwolonego użytku publicznego, można z tej kategorii licencji ustawowych wyróżnić pięć subkategorii:

- nadawczą - obejmuje ona równoczesne i integralne rozpowszechnianie za pomocą sieci kablowej lub anteny zbiorowej niekomercyjne odbieranie z wykorzystaniem odpowiednich urządzeń nadawanych utworów (art. 24 ustawy o prawie autorskim i prawach pokrewnych),

- informacyjną - obejmuje możliwość rozpowszechniania bez zgody twórcy jego utworów w celach informacyjnych i sprawozdawczych (art. 25 i 26 ustawy),

- dydaktyczno-naukową - obejmuje możliwość rozpowszechniania utworów dla celów dydaktycznych, oświatowych, naukowych i dokumentacyjnych (art. 27-30 ustawy),

- poświęconą uświetnianiu wydarzeń publicznych - obejmuje możliwość rozpowszechniania utworów dla celów uświetnienia uroczystości religijnych, państwowych (art. 31 ustawy),

- poświęconą propagowaniu utworów plastycznych (art. 32-33 ustawy).

Cechami wspólnymi łączącymi dozwolony użytek publiczny oraz odstępstwo rolne jest po pierwsze, ograniczenie zakresu przedmiotowego tych instytucji prawa. Zarówno w przypadku dozwolonego użytku publicznego, jak i odstępstwa rolnego, licencją ustawową objęte są jedynie pewne kategorie dóbr podlegających ochronie. 
Po drugie, elementem wspólnym dla tych instytucji jest uznanie przez prawodawcę, że podstawą dla ograniczenia na ich zasadzie wyłącznego prawa niematerialnego jest szczególnie istotny interes społeczny. Odmiennie niż w przypadku dozwolonego użytku prywatnego, interes społeczny nie jest w tym wypadku utożsamiany z potrzebą zaspokajania wyższych potrzeb jednostki, lecz nacechowany jest dbałością o szerzej pojmowane dobro ogółu.

Dozwolony użytek publiczny oraz odstępstwo rolne wykazują jednak również pewne zasadnicze różnice. Dozwolony użytek publiczny jest licencją ustawową o szerszym zakresie, niż ma to miejsce w przypadku odstępstwa rolnego. Ukierunkowany jest na szeroki krąg odbiorców tego ustawowego przywileju, w zasadzie nieograniczony w żaden sposób. W odmienny sposób uregulowano problematykę wynagrodzenia podmiotu uprawnionego z tytułu wyłącznego prawa na dobrach niematerialnych. W przypadku odstępstwa rolnego zasadą jest konieczność wniesienia przez korzystającego z licencji umownej stosownej opłaty. Dozwolony użytek publiczny jest uprawnieniem, które zasadniczo wolne jest od obowiązku zapłaty wynagrodzenia, a obowiązek taki powstaje jedynie sporadycznie.

\section{Konkluzje}

Dążąc do podsumowania tematu, można pokusić się o wniosek, że odstępstwo rolne jako licencja ustawowa swoim charakterem prawnym najbliższa jest licencji ustawowej prawa autorskiego - dozwolonemu użytkowi publicznemu. Posiada ona jednak wiele cech swoistych, takich jak:

- szczególny rodzaj dobra społecznego realizowanego za pomocą instytucji odstępstwa rolnego - jest to dobro o charakterze podstawowym,

- szczególny sposób ukształtowania ograniczonego kręgu adresatów przywileju wynikającego ze stosowania tej instytucji prawa,

- szczególne zasady bezpośredniego ponoszenia opłat z tytułu korzystania $\mathrm{z}$ instytucji odstępstwa rolnego.

Wszystkie te specyficzne cechy przemawiają za uznaniem tej instytucji za odrębną licencję ustawową prawa rolnego. 


\section{Agricultural exception against a background another licence agreements}

\section{Summary}

The institution of "agricultural exception" involves the legally permitted possibility of departing from the accepted system of protecting plant varieties in order to secure the interest of farmers. This institution of the law allows them to pursue their interest by using, in their own farmsteads, harvested material from a protected variety as sowing material without having to obtain the cultivator's consent, against adequate payment or without the obligation to make any payment.

If one perceives agricultural exception in such a way, its legal nature makes it enter into the wider category of statutory licences related to non-material interest. The shape of the institution makes it resemble permitted private use, and in particular permitted public use, i.e. statutory licences related to copyright. However, agricultural exception has a number of properties that make it differ from statutory licences related to industrial property or copyright. The following features make agricultural exception differ from other statutory licences:

- the specific fundamental nature of the public interest that agricultural exception contributes to (securing the food security of a country),

- the specific manner of shaping of a limited group of entities the privilege is intended for, resulting from the application of this institution of law (it relates exclusively to farmers),

- the specific rules related to the direct payment of fees by the entities benefiting from the rule of agricultural exception: the fees are paid directly to the cultivators who are authorised to receive them under their exclusive right to the respective varieties.

All these specific features constitute arguments for considering the institution of agricultural exception as a separate statutory licence of the agricultural law. 